\title{
Varieties of euro adoption strategies in Visegrad countries before the pandemic crisis
}

\author{
PÉTER ÁKOS BOD ${ }^{1 *}$ [D, ORSOLYA PÓCSIK ${ }^{2}$ [ \\ GYÖRGY IVÁN NESZMÉLYI ${ }^{3}$
}

\footnotetext{
${ }^{1}$ Department of Economic and Public Policy, Corvinus University of Budapest, Budapest, Fővám tér 8, H-1093, Hungary

${ }^{2}$ Doctoral School of Management and Regional Sciences, Institute of Sustainable Development and Management, Hungarian University of Agriculture and Life Sciences, Gödöllö, Hungary

${ }^{3}$ Department of Commerce, Hospitality and Tourism, Budapest Business School and University of Applied Science Faculty of Commerce, Hungary
}

Received: December 22, 2020 • Revised manuscript received: February 21, 2021 Accepted: March 11, 2021

() 2021 The Author(s)

\begin{abstract}
The enlargement of the euro area (EA), an unfinished process, was low on the European agenda in the period between the 2008 and the 2020 crises. The socio-economic consequences of the coronavirus pandemic and frictions in geopolitics would call for a coherent Europe, yet new and old fault-lines appeared in the EU involving the eastern periphery where sovereignty issues gained particular importance. The authors revisit the euro adoption process of the new member states, with a focus on the Visegrad Group (V4) countries, applying a two-track approach: a monetary policy analyses of EA entry as a rational cost/ benefit issue and, second, a political economic survey of key stakeholders, set in the context of the dilemmas of retaining or sacrificing nominal monetary sovereignty. Even a piecemeal enlargement of the EA, involving Bulgaria, Croatia and Romania, would cause business consequences and political repercussions in the countries left out of EA. The paper concludes that further moves towards a developmental state model would preclude euro adoption and put such member state in collision course with the core Europe.
\end{abstract}

\section{KEYWORDS}

Central and Eastern Europe, euro adoption, economic policy, middle- income trap

\section{JEL CLASSIFICATION INDICES}

E63, E65, F15, F45, P26, R5

*Corresponding author. E-mail: petera.bod@uni-corvinus.hu 


\section{INTRODUCTION}

\subsection{A new context for currency reforms}

Europe was exposed to hard tests in the 2020 crisis. Old and newer fault lines reappeared in the European Union (EU) in the wake of the pandemics, cleavages of national interests emerged somewhat unexpectedly, and former certainties, such as free movement of persons and public support to the rule of law were shaken.

This was the second shock in recent times. The 2008 international financial crisis hit the European economies in asymmetric ways, and triggered divergent tendencies. It made the constituent states and the EU institutions reconsider governance designs and policy measures. The 2020 pandemic, symmetric in its nature, came at a time when EU's internal cleavages became more manifest than never before, signified by the departure of the United Kingdom, emergence of strong anti-EU movements in some member states, and vocal dissent by some governments concerning the future design of the integration, culminated in the threat of the Hungarian - Polish tandem to veto the European budget and the post-pandemic resilience fund.

Tensions and shifts in global power relations, such as growing frictions in international trade and the troubling geopolitical emergence of China, would provide strong arguments for progressing toward a more coherent Europe, with the euro as a key instrument, the euro area (EA) as a central institution, and a powerful EU budget to support coherence, competitiveness and sustainability.

During the pandemics, political attention was focussed on budgetary issues - the seven-year budgetary framework and the Next Generation European Union (NGEU) initiative, in particular. Monetary aspects of the European integration process were given, for the time being, less attention. The unfinished issue of EA enlargement had remained outside the centre of policy debates in the EU or in the countries concerned for some time. Yet, new developments have emerged lately, adding to the topicality of the euro issue. Three member states on the southeastern flank of the EU dedicated themselves to adopt the euro: Bulgaria and Croatia entered the European Exchange Rate Mechanism (ERM) II in July 2020, and Romania officially set a (new) target date of 2024 for euro adoption. That left, by the time of the coronavirus crisis, the Czech Republic, Hungary and Poland, members of the regional Visegrad grouping, as outsiders, even without a target date, while Slovakia, also a V4 country has been an EA member since 2009.

Our research process has acknowledged that a currency regime choice such as the euro adoption is, on the face of it, a monetary policy act, but one that involves multiple key stakeholders in a par excellence political process. This is why the approach should incorporate monetary policy, general economic policy as well as political aspects; all applied to a particular regional grouping within the EU. Our research approach, as based on a large but heterogeneous body of academic research and policy analyses, assumes that the euro adoption for business actors is predominantly a rational cost/benefit issue; yet for many other key stakeholders (the general public, governments, central banks and political parties) the framework of reference is sovereignty status with cost/benefit consequences (Bod et al. 2021). This is our context for offering insights about feasible policy options for the parties concerned.

\subsection{The state of play when COVID hit the world}

At the time of writing, 19 out of $27 \mathrm{EU}$ member states use the euro as their sole legal tender. Denmark has a special status as it was granted an opt-out in 1993, thus it does not have to 
participate in the third stage on the Economic and Monetary Union (EMU). Sweden was given the status of a 'member state with a derogation' in 1998, then the 2003 referendum turned down euro adoption, and the authorities intentionally avoid fulfilling one entry condition (i.e., taking part in ERM). All other present member states, however, had committed themselves to adopt the euro under the Treaty on the Functioning of the EU upon fulfilling the entry test (Maastricht criteria).

The Treaty, however, did not set a timetable to meet the entry criteria. ${ }^{1}$ In the concerned countries it was well understood that the national currency could not be retained indefinitely. It is important to note that the general public and the political classes alike acknowledged that an applicant to the EU was obliged to adopt the common European currency in due time. Initially, the public attitude was mostly very supportive across the region. As we will see, intensity of the support changed by the time. Meanwhile the euro project itself experienced tensions and challenges - a topic that will not be addressed here in detail. Nor will we investigate all country cases: we focus on the Central Eastern European (CEE) region and more particularly the Visegrad group (V4 - in short).

What follows, first, is a retrospective analysis of the economic, financial and political evolution of CEE since the change of the socio-economic system, with particular emphasis on the V4: Czech Republic (or Czechia in short), Hungary, Poland and Slovakia. Second, a political economic analysis will be applied to the euro adoption process of the concerned countries, set in the context of the dilemmas of retaining or sacrificing nominal monetary sovereignty. Third, the political and economic policy aspect of this monetary sovereignty dilemma will be related to an underlying issue of the development paths that the CEE states may or may not choose to take. Finally, a reference is made to the potential consequences of the COVID-induced economic tensions for the unfinished euro project.

\section{SIMILAR CHALLANGES AND DIFFERENT REACTIONS}

\subsection{On macroeconomic, political and monetary diversity of CEE}

Among the V4 countries, the currency system variability is particularly noteworthy. The 'big bang' EU enlargement of 2004 and the subsequent accession of another three countries led to a diversified monetary landscape. ${ }^{2}$ Slovenia was the first CEE country to enter the EA in 2007, followed by Slovakia on 1 January 2009, just at a time when Europe - including the CEE region - was hit hard by the sub-prime crisis. Shortly after the crisis, Estonia (2011), Latvia (2014) and Lithuania (2015) became members of the EA. Meanwhile, Poland, Hungary and Romania maintained a floating exchange rate regime, with the latter designating 2024 as a target year for gaining EA membership. Bulgaria had pegged its currency under a currency board arrangement long before it joined the ERM II in July 2020. Before being included in the ERM II in 2020, Croatia had applied a managed floating exchange rate regime. As regards to the monetary practice of Czechia, it had applied managed and also free-floating arrangements at one time or another.

\footnotetext{
${ }^{1}$ For the legal framework, see the bi-annual convergence reports of the European Central Bank (ECB).

${ }^{2}$ Cyprus and Malta also participated in the 2004 enlargement and adopted the euro as early as 2008. Their cases, and that of Sweden, are not discussed here.
} 
As distinct from the earlier cases of the United Kingdom and Denmark, the new member states were not granted the option to stay out; all these countries, upon their accession to the EU, committed themselves to adopt the single European currency. The Maastricht Treaty defined the rules for changeover but left the member states a great deal of leeway in the timing of their respective EA entry. Apparently, they took advantage of the flexibility afforded by the rules.

This analysis is focused on the V4, contrasting the Slovak case with those of Czechia, Hungary and Poland. The analysis, given the complexity of the issue, covers economic theory and monetary policy aspects as well as political decision-making. By the time of 2020, a crisis year, Slovakia had amassed more than a decade of experience of EA membership; the remaining three Visegrad states and three countries of the South-East European region (Bulgaria, Romania and Croatia) had gained experience in national monetary policy making - inviting the scholars of currency unions to study the comparable cases.

While there are many differences among the mentioned six countries, not the least concerning their post-socialist heritages, they all face a common challenge: their economies are at cross-roads. They are, on the one hand, deeply integrated into the EU economy, de facto into the EA. Most are, on the other hand, still behind in terms of having knowledge-intensive, high added-value businesses. Their middle-income situation may evolve into what can be labelled as a trap, i.e. being stuck in an intermediate stage in the development trajectory - a concept applied originally for the newly industrialized East and Southeast Asian economies or Latin American countries (Gill - Kharas 2015; Murach et al. 2018).

This aspect will also be considered in our review of political attitudes to the euro adoption. Divergent policy orientations may be interpreted as varieties in efforts to deal with the 'trap', if there is one. The fact that Slovenia, Slovakia, and somewhat later, the Baltic states gave up their autonomous monetary policy by adopting the euro, and Romania, Bulgaria and Croatia proceeded towards it, may be seen as a political decision to fasten convergence to the European mainstream. In contrast, the governments of Czechia, Poland and Hungary remained reluctant towards the euro adoption, each with its own particular monetary and political considerations in the background. Such considerations imply the intention of using the exchange rate and/or central bank interest rates for improving external competitiveness and for stabilizing the economy. Yet, adoption of euro, as we have documented, frequently appears in political discourse as a kind of surrender of sovereignty or being melted into the "united Europe".

The political arguments and viewpoints still differ in all concerned countries. Political approaches are rooted in the past. The role of state, the concept of nation-state, and the principle of sovereignty are interpreted, understood and valued in the CEE region in ways that are different from those in the Western and North European countries. The value gap can be frequently observed in policy debates and in the decision-making processes in the Council of the European Union and in other European institutions.

\subsection{The choice of exchange rate regime: economic cost-benefit analysis and more}

At the time of the EU accession, central banks, government agencies and think-tanks studied the probable benefits and costs of the EA membership (see particularly, Csajbók - Csermely 2002; Borowski 2004; Šuster 2006). Their final conclusions supported the EA entry. The fact that the Hungarian, Slovenian and Slovakian governments, in particular, seriously envisaged early euro adoption at that time, gave policy relevance to such professional analyses. Subsequent events 
have demonstrated, however, that rational economic considerations do not really determine practical government decisions.

The second decade of the political transition around 2000 began in buoyant external conditions. The boom of the early 2000s, however, was suddenly stopped short by the 2008 financial crisis and the ensuing internal tensions of the EA. The impact of these developments on macroeconomic paths - and likewise, on policy approaches - varied across the EU periphery, as demonstrated by the diversity of cases seen in Ireland, the Mediterranean and the CEE region. The dilemma of euro adoption vs. retaining national currency appeared in the new lights. Still, some of the new EU member states proceeded to accomplish the euro changeover. In the countries where the euro had been adopted, research mainly focused on the economic consequences (Lalinský 2010; Zeman 2012). In the non-euro area countries, professional debates, of varying intensity, considered the risks and merits of an eventual entry, and the technical issues of the longish euro adoption process. ${ }^{3}$

Academic analyses and recommendations are always conditional; their wording is refined as professionals refrain from direct political statements. Consequently, professional studies do not impose strong pressure on policymakers. The conclusions of academic or central bank analysis are context-dependent and allow for various interpretations; since analysts employ various assumptions with regard to the intentions of the policymakers, all calculations are open to debate.

Ultimately, the de jure abandonment of the national currency is a decision of a political nature. This is not a new recognition. As pointed out by Fritz Machlup half a century ago in his summary of theoretical debates about the concept of the optimum currency area (OCA), establishing a currency area ultimately hinges upon the intentions of the prospective members (their governments, that is), whether they are willing to give up their independence: "Pragmatically, therefore, an optimum currency area is a region no part of which insists on creating money and having a monetary policy of its own."(Machlup 1977: 71).

At first sight, Machlup's proposition may appear tautological unless we scrutinize its underlying assumptions carefully. In a democracy, the following assumptions ought to hold concerning the attitude of a government contemplating currency area entry: a) the government is aware of the cost-benefit analyses of the monetary options; b) it recognises the interests of all major stakeholders; and c) in making decisions it acts in accordance with the majority interests of society, as opposed to its own self-interest. In reality, no above aspect can be taken as given:

\footnotetext{
${ }^{3}$ In the Hungarian academic and analyst community, the first wave of the topic commenced with reports published in 1999 by the research institutes commissioned by the Ministry of Finance for laying the groundwork for the government's position as part of the preparations for the EU membership and subsequently, the adoption of the euro. The position of the Central Bank of Hungary (MNB) was adopted in 2002 (Csajbók - Csermely 2002). In the following years of serious deterioration of Hungary's fiscal position, the topic was temporarily set aside, brought up again from time to time (Darvas - Szapáry 2008). In the aftermath of the 2008 financial crisis and subsequently, the political turnaround in 2010, a new situation presented itself. Both the realities thereof and the ongoing turbulences of the Eurozone were considered by participants of the debate initiated in the keynote paper in the leading Hungarian academic journal (Neményi - Oblath 2012). After a gap of several years (as indeed, the government showed no intention to adopt the euro and the new order of the EA was just beginning to take shape), debates reappeared in 2017 about the timeliness of the Maastricht criteria and the actions to be taken during the pre-intervention period. The topic was revisited once again in 2019 in Hungarian journals, see the summary of the renewed debate in Palánkai (2020) who concluded supportive of eventual EA entry. Publications released by the MNB, however, were rather sceptical in this regard (see e.g., Virág 2020).
} 
politicians are frequently unaware of the overall economic cost/benefit consequences of their decisions (or non-decisions); they do not always strive to learn the position of all stakeholders; and politicians may not always defer to the public good in their decision-making practice.

In any event, we may conclude from the various cases of the currency decisions made in the new EU member states that the professional analyses of the net balance of economic costs/ benefits did not matter much. The majority preferences of the society and the positions of significant stakeholders were not always taken into account, either. The decision-makers were likely to follow their own political interests in their decisions. This is the implicit conclusion of J. Horvath who applied Machlup's statement to government decisions in the CEE region: "We observe an interesting situation: countries with similar structural economic characteristics opted for different exchange rate regimes. For example, the Czech Republic opted for managed float while Slovakia joined the Eurozone; Romania introduced float and Bulgaria a currency board; Serbia and Albania have floated while other western Balkan countries introduced various fixed exchange rate regimes." (Horvath 2014: 60).

Slovakia is referred to in economic literature, documents of international organisations and business publications alike as a convergence success story of the region. ${ }^{4}$ Macroeconomic data do indicate that Slovakia moved on a successful macroeconomic path, on balance, in the years following the introduction of the euro - a fact that is often cited in the debates on the EA membership. Yet, the exchange rate regime or the whole monetary policy system will hardly explain alone an economy's success beyond doubt. Still, the case of Slovakia is especially interesting as all Visegrad countries are similar in economic structure, but their official attitudes to the euro (among other things) are different.

Below, we address the broader economic policy embeddedness and the institutional characteristics of the currency decision, as these two aspects are often overlooked in macroeconomic analyses. We also review the microeconomic consequences of the EA membership; again, these topics are barely touched upon in the theoretical literature.

\subsection{Slovakia's euro area membership in CEE context}

Slovakia officially adopted the single European currency on 1 January 2009. ${ }^{5}$ A peculiar, unforeseen feature of this timing was that the euro changeover in Slovakia coincided with a most critical moment of the global financial crisis. This circumstance sends a warning to the policy analysts: random, unpredictable events - in other words, good or bad luck - may assume a crucial role in the momentous decisions and in the unfolding of the consequences.

\footnotetext{
4"Slovakia is an economic success story." This is the opening statement of the 2017 Country Report of the IMF (2017: 2).

${ }^{5}$ Concerning Slovakia's euro adoption, some authors claim that the timing of Slovakia was lucky as the Maastricht test in particular, the fiscal criterion - was easier to meet in the pre-crisis period of economic boom compared to the case of Estonia, for example, which joined two years later in January 2011 (Fidrmuc -Wörgötter 2013). Undoubtedly, in the period preceding the autumn of 2008 - i.e., in an environment of exceptionally dynamic growth - it was objectively easier to push the deficit-to-GDP ratio below the benchmark. Still, this step required a great deal of determination as indeed no other country implemented fiscal consolidation measures during the same years, as also evidenced by the trajectory of the Hungarian economic policy in 2001-2006. True, policymakers would not have been able to attain the inflation targets in the overheated boom period without two successive revaluations of the Slovak koruna. With the second intervention, Slovakia - already an ERM II member - resorted to the maximum revaluation (15\%) permitted by the rules of the exchange rate mechanism.
} 
The Slovak koruna had been twice revaluated - with the approval of the European Commission, the European Council (specifically, the ECOFIN Council) and the ECB - before the conversion rate of euro/SKK was irrevocably fixed in the summer of 2008. That was still a relatively calm period at the peak of the business cycle of the region. A radical turn, however, was looming on the horizon. By the time of the completion of the changeover in January 2009, the exchange rate fixed in the summer turned to be overvalued (Firdrmuc - Wörgötter 2013). This is especially true in the Slovak - Hungarian relations: Hungary, badly hit by the financial crisis, suffered a sharp currency depreciation at end-2008 from about 230 EUR/HUF to over 270, despite all efforts of the national bank to stabilise the EUR/HUF exchange rate.

Thus, what happened due to the unintended events was that should be avoided by all accounts when fixing an exchange rate: Slovakia entered the currency area with an excessively strong rate. Scholars of euro accession had been deeply troubled by the poor competitiveness already apparent at the southern periphery of the EA. As Blanchard explained concerning the Portuguese experience with the euro: due to the dramatic reduction of nominal and real interest rate under the EA membership, consumption and investment activity surged, wage costs grew, while the improvement in productivity came to a halt; and being in the EA already, escudo devaluation, a traditional tool, was no longer an option (Blanchard 2007). In the case of Slovakia, however, unit labour costs (ULC) did not balloon in the years preceding the euro adoption thanks to the continuous and significant improvement in labour productivity, and the labour market was more flexible than in Portugal. Experts reasonably expected that the Slovak economy - which had become increasingly integrated with the German economy - would keep modernising and, supported by the additional business benefits from the EA membership, competitiveness would not pose a problem to the extent seen in the rapidly deindustrialising southern periphery.

Looking at the developments of the following few years, we cannot see any sign of price noncompetitiveness that occurs so frequently when currencies are fixed at strong exchange rate. The critical factor is the dynamic rise of productivity; the EU institutions had taken this favourable trend into account when deciding to support the two-koruna revaluations in the run-up to the final fixing of the exchange rate.

This raises the obvious question: what were the reasons and circumstances that allowed productivity growth in the Slovak economy before and after the adoption of the euro? This is an especially intriguing question from the perspective of Hungary where productivity stagnated in the period under review. ${ }^{6}$ The contrast between Hungary and Slovakia became particularly sharp at the end of 2008 when Hungary became the first EU member state to turn to the IMF and the EU for a stand-by credit facility. (Labour productivity and related microeconomic issues will be dealt with in Section 3.)

As for the timing of the changeover, pure luck came into play, as put, modestly, by the director of the Research Department of the National Bank of Slovakia (NBS) (Šuster 2014: 70). Slovakia's entry in early 2009 was fortunate in the sense that the expected changeover-related inflation failed to materialise amid the general recession; NBS subsequently estimated the oneoff rounding/re-pricing effect in the range of 0.0 and $0.19 \%$ (Šuster, ibid). Unlike in other

\footnotetext{
${ }^{6}$ In a paper on Hungarian economic policy, Csillag (2020) placed special emphasis on the aspect of productivity.
} 
countries, the general public of Slovakia did not perceive an increase in prices after the changeover.

Euro adoption is a process stretching at least four years; in the case of Slovakia, the government had taken the entry decision as early as 2003, already before the country's official accession to the EU. The national changeover plan was drawn up in 2005, and Slovakia joined the ERM II soon after that. Eventually, the final fixing took place on 28 May 2008. Consequently, we need to step back in time for several years to understand the economic, professional and political circumstances behind the key decisions. We should even backtrack to the beginning of state-building in Slovakia in order to resolve an apparent contradiction, namely: a newly founded state commits to giving up its national currency at the first possible opportunity.

\subsection{Peculiar historic antecedents: the separation of Czechoslovakia and the first decade of Slovak state-building}

After the 'velvet revolution' of autumn 1989, Czechoslovakia went through a rapid regime change, leaving behind a rigid planned economy system in the process. The economic structure that it inherited was predominantly industrial - considered developed according to the Communist doctrines, with high share of manufacturing and industrial exports. As all other CMEA member states, ${ }^{7}$ socialist Czechoslovakia relied heavily on the Soviet export market and on raw material imports. After the swift and surprisingly deep Soviet-Russian economic crisis and the sudden dissolution of East Germany (GDR), the eastern relations of the Czechoslovakian economy drastically deteriorated in 1990-1991. Defence industry plants and state-owned heavy industry companies located in the Slovakian region were hit particularly hard by the end of the old system of product specialisation. Thus, the early 1990s saw a severe downturn: in 1991 industrial output dropped by a third, real wages declined by $27 \%$ and personal consumption by $37 \%$ on year-on-year basis.

During the transition, significant regional disparities appeared in all former socialist countries in terms of production decline, unemployment and foreign direct investment (FDI) indicators. Czechoslovakia was no exception in this regard: the disparities between the Czech and the Slovak regions manifested themselves all at once. ${ }^{8}$

Due to earlier heavy industry projects, the development gap between the two parts of the country, according to the official indicators, had closed almost completely in the 1970s; still the Slovak region did not keep converging to the Czech parts any further in the 1980s. In fact, as in Hungary and Poland, the forced industrialisation policy had created industrial capacities that eventually proved to be uncompetitive and oversized, and they soon became liabilities for the economy. Per capita GDP in the Slovak part amounted to only two thirds of the corresponding

\footnotetext{
${ }^{7}$ The Council for Mutual Economic Assistance (CMEA) was an economic organization from 1949 to 1991 to facilitate and coordinate the economic development of the Soviet-bloc countries in Central and Eastern Europe.

${ }^{8}$ During the one-party period, the Czechoslovakian statistics grossly underestimated the gap of the eastern part of the country in level of development claiming that the Slovakian value was estimated at $90 \%$ of the national income average. This optimistic view - hard to consider unbiased in light of the political data manipulations of the era - can also be attributed to the fact that the post-1968 regime had, in fact, implemented significant military, chemical and energy projects in the Slovak area. At the end of the 1980s, the Slovak region accounted for $60 \%$ of Czechoslovakia's military production (Fidrmuc et al. 1999).
} 
Czech value in 1992 (Kafkadesk 2018), and the outlook was alarming. The political changeover itself delivered an asymmetric shock to the two parts of the country: while unemployment was already 8.4\% in the country as a whole in April 1992 - which is an enormous change compared to the former (formal) full employment - in the Slovak part the unemployment rate exceeded 12\% (Engelberg 1993).

Although sensitivities and resentments flourished between the Czech, Moravian and Slovak sides of the society during the existence of Czechoslovakia, the majority of the population did not wish to terminate the common state. ${ }^{9}$ Yet, the official dissolution on 1 January 1993 took place peacefully and relatively smoothly. Shared assets, including foreign exchange reserve, public debt and military equipment were divided at a two-to-one ratio reflecting the respective populations of the parts. Under the arrangement, the two countries remained in a customs union despite the split, citizens were allowed to travel through the border without passport control, and the common currency was to be maintained for some time. ${ }^{10}$

\subsection{Fiscal and monetary independence - without a grand design}

Although a monetary union was formally established between the two new entities, it was established without a joint central bank and meant as a transitory arrangement. Life soon took a sharp turn: due to the flaws of cooperation between the Czech and the Slovak national banks and the surge in currency speculation in particular, the common currency - the Czechoslovak koruna - was dispensed as early as February 1993. The new monetary authorities of the now independent states put separate legal tenders into circulation, initially at the same official exchange rate. Slovakia, however, had to devalue its koruna by $10 \%$ in June 1993. Essentially, this step confirmed the depreciation expectations; speculative investors succeeded in instigating a forced devaluation.

Slovakia, a new state, learned quickly a hard lesson on the realities of nominal monetary independence. External business views were sceptical about the outlook of the newly established Slovak state. Right after the breakup, international credit rating agencies perceived the Czech and Slovak government securities differently: the Czech Republic received investment grade credit rating from the start, Slovakia was, however, assigned a BB rating - i.e., speculative grade at its very first test (the Hungarian rating fell between the two at that time).

\footnotetext{
${ }^{9}$ In 1992, the dissolution negotiations between Václav Klaus and Vladimír Mečiar were conducted behind closed doors from the start and, rejecting the petition signed by 2.5 million 'Czechoslovaks' for a referendum, the leaders practically presented society with a fait accompli (Engelberg 1993). The real reason for the - otherwise peaceful but hardly democratic - split-up is a matter of debate to this day; the personal ambitions of the politicians concerned and the revival of the notion of national identity were equally likely contributors. In addition, in view of the poorer socioeconomic status of the Slovak region, the prospect of 'having to support' the Slovak region if the federal state was to be maintained was undoubtedly one of the concerns on the Czech side. It was known - although the actual numbers were not disclosed - that the eastern regions were the recipients of substantial fiscal transfers within the territory of socialist Czechoslovakia, as was also the case in the preceding democratic era, before WWII. The breakup would put an end to the re-channelling of the domestic income flows. The Czech decision-makers were probably also influenced by the recent experience of German unification; the staggering costs of the convergence measures for the economically inferior eastern regions had been disclosed by then (Fidrmuc et al.1999).

${ }^{10}$ Today, living in the EU and within the Schengen area, the existence of a customs union and free movement might be taken for granted, but it was hardly self-evident in the period under review.
} 
As regards the subsequent evolution of the exchange rates, the Czech koruna, as predicted, kept strengthening against the Slovak koruna (SKK). However, the exchange rate of the SKK stabilised over time. In this regard, a remarkable CEE divergence can be observed in the second half of the thirty-year period under review: while the Hungarian and the Romanian currencies depreciated substantially on the longer term - with large fluctuations - against the euro, both the Czech and the Slovak currencies tended to strengthen in the period between 1999 and 2008. The Czech koruna remained fairly stable thereafter, but its rate notably approached the SKK exchange rate at which the Slovak currency was irrevocably fixed in the summer of 2008, which may have given a sense of gratification to the Slovaks. The fact that these two countries with floating rates did not (and probably could not) use the exchange rate as an instrument to support international competitiveness through devaluation must provide food for thought to the fans of floating.

The first few noisy years after the break-up of Czechoslovakia led experts to conclude that the successor states were ill-equipped to form an optimum currency area due to the differences in their economic structures. The collapse of the Czech-Slovak currency union, therefore, was not unwarranted in economic sense (Fidrmuc et al. 1999). Yet, the later development of the two countries within the European Union, the narrowing income gap between them may well substantiate a contradicting conclusion. In any case, the role of politics was crucial. The first years of state-building under the leadership of Slovak Prime Minister Vladimír Mečiar (1990-1998) were mired in difficulties. ${ }^{11}$ The output contraction - which was far more drastic than the one suffered by the Czech economy - can be attributed to numerous reasons, including the immediate discontinuation of intra-national transfers, the sudden collapse of military production brought about by the peace, losses were arising from disruptions in the eastern European relations and, to a significant degree, the character of government policy.

Political conditions in Slovakia had undoubtedly hampered the return to market economy. ${ }^{12}$ While significant FDI inflows were directed to the region, independent Slovakia received relatively less of it. Economic growth, however, began to accelerate over time; in the period of 19941998 its annual average exceeded 5\%, although the base was far below the initial levels of Hungary and, especially, Czechia. Even this growth materialised amid substantial twin deficit. In 1996-1998 the current account deficit levelled off at 10\% of GDP, and fiscal deficit rose to 6\%. Preserving its independence from the start, the central bank attempted to offset the expansionary fiscal policy with restrictive monetary policy, but the high real interest rate level undermined investments and increased the debt servicing costs of the government. Meanwhile, not only did the government fail to clamp down on corruption effectively, it exacerbated corruption by lack of transparency in the privatisation of state property (Mikloš 2008).

\footnotetext{
${ }^{11}$ With a left-wing/populist stance, the Mečiar governments drew a great deal of rightful criticism. The fact that in this period Slovakia clearly lagged behind the rest of the CEE countries in terms of integration into the international economic order can be attributed to the combination of numerous factors, such as the lack of transparency in Slovakia's privatisation processes, the government's inexperience in international affairs and its worrisome friendship with Russia. This was also evidenced by Slovakia's late admission (in 2004 as compared to the Czech Republic and Hungary: 1999) to NATO and to the OECD (Czech Republic: 1995, Hungary: 1996, Slovakia: 2000). In this period many participants expected Slovakia to enter the European Union at a later date than the rest of the countries in the region. As it turned out, all countries of the region joined the EU concurrently on 1 May 2004; however, Slovakia was the last of the ten candidate countries to complete the admission negotiations.

${ }^{12}$ As pointed out by Ivan Mikloš, former Czech-Slovak Minister for Privatisation and subsequently Minister of Finance of the Slovak Republic, Meciar's governments pushed the country into economic isolation and all, but drove it "to the edge of collapse" (Mikloš 2008).
} 
It became evident to the general public that Slovakia wouldn't become a trusted partner as long as Mečiar was at the helm, and it would have no chance to be admitted to the EU in the first round, even though that was a clear national objective. The economic situation did not improve much, and the society became increasingly disappointed over public affairs. The 1998 elections marked an important political turnaround. With Mikulás Dzurinda as Prime Minister, the new government commenced the long-overdue macroeconomic stabilisation. Overcoming its integration deficit, Slovakia became able to catch up with other Visegrad countries in the negotiations for EU membership. Subsequently, in its second term the government adopted deep structural reforms.

\subsection{Consolidation period as a prerequisite for euro adoption}

The period of 1998-2006 can be viewed as the country's transformation to a true market economy, whereby Slovakia was admitted to the group of potentially successful regime changers. Yet, the period was fraught with tensions as radical reforms elicited negative accompanying phenomena, such as a persistently high unemployment rate: in the dynamic period of 2000-2004, the official unemployment rate moved within a range of $18-20 \%$, a negative European record at the time, which was deemed a destabilising factor also in the external assessments (IMF 2005).

The $2^{\text {nd }}$ Dzurinda government, elected in 2002, recognized the need to accelerate the reform process and to adopt an economic policy that put the economy on a sustainable growth path. To that end, the government intended to increase the level of economic freedom and improve both macroeconomic framework conditions and the business environment. Key elements of the 2004 government programme included a tax reform with the introduction of a $19 \%$ flat-rate personal income tax, VAT and corporate income tax scheme. A pension reform of enormous political significance was adopted, with a retirement age increase starting from 2004, and a second pillar to the pension system was introduced along with a 'visit fee' under the health reform. Continuing the labour market reforms adopted during the previous government cycle, the rules of overtime were eased (IMF 2005; Mikloš 2008).

Many citizens were, however, hit hard by the tightening of the eligibility requirements for social support and the reduction of unemployment benefits; these reforms sparked significant social resistance. At the same time, the policy direction aimed at the improvement of the business environment stimulated capital inflows and greatly contributed to the acceleration of economic growth to a rate of $6 \%$ by 2005 . Consequently, the income convergence of Slovakia took an enormous step forward; Slovakia caught up to Hungary's per capita GDP and even surpassed it in that period. The yields of economic dynamics, however, were distributed disproportionately across society. External praise and improvement in the nation's reputation could not compensate a wide range of people who bore the brunt of the reforms. As evidenced by subsequent political developments, the society failed to offer sufficient public support for reforms of this severity. However, in light of the dynamics of the reform momentum, it is not surprising that the government decided in 2003 on an early euro area accession. ${ }^{13}$

\footnotetext{
${ }^{13}$ The economic reforms and their results improved the international perception of Slovakia much. Upgrades in the medium-term sovereign credit ratings indicated the improvement perceived by rating agencies. Under the Dzurinda governments, Slovakia transformed from laggard to vanguard in many regards. This assessment is reflected in the 2005 Article IV consultation document of the IMF which stated the following: "Slovakia's economic performance is benefiting from good policies. This performance has been favourable compared to regional standards" (IMF 2005: 6).
} 
Table 1. Macroeconomic indicators of Slovakia before and during euro adoption (\%)

\begin{tabular}{|l|r|r|r|r|r|r|r|r|r|}
\hline Indicator & 2002 & 2003 & 2004 & 2005 & 2006 & 2007 & 2008 & 2009 & 2010 \\
\hline GDP growth & 4.6 & 4.5 & 5.4 & 6.0 & 8.2 & 8.0 & 6.2 & -4.7 & 4.1 \\
\hline Consumer price index & 3.1 & 8.6 & 7.6 & 2.7 & 4.5 & 2.8 & 4.6 & 1.6 & 1.0 \\
\hline Unemployment rate & 18.6 & 17.5 & 18.1 & 16.2 & 13.5 & 12.2 & 9.5 & 12.1 & 14.1 \\
\hline Labour productivity growth & 0.7 & 0.7 & 0.7 & 0.8 & 0.8 & 0.9 & 0.9 & 0.9 & 0.9 \\
\hline $\begin{array}{l}\text { Current account balance (as \% of } \\
\text { GDP) }\end{array}$ & -8.0 & -0.9 & -3.5 & -8.5 & -7.0 & -5.4 & -6.6 & -2.6 & -2.8 \\
\hline
\end{tabular}

Source: IMF Article 4. documents.

During the 'halcyon years' of the region, the Slovak economy advanced the most compared to other Visegrad countries in areas in which it had lagged behind its peers in the first decade of the independent state: productivity and capital attraction ability. The favourable changes in the Slovak economic data (see Table 1) are especially noteworthy in the historic moment of its EU accession when the new state surpassed in a number of important aspects the performance of its neighbours making up its national benchmarking framework. ${ }^{14}$

From the perspective of the political conditions and economic interrelationships of the early 2000s, the entry of Slovenia, Slovakia and the Baltic states was a logical decision; it is rather the case of the countries that did not join at the time that warrant deeper analysis.

\subsection{Slovakia - the first, so far, Visegrad country in the eurozone}

Despite the economic successes and the merits earned for obtaining the EU membership, the general elections of 2006 ended the Dzurinda years that had proved to be so important and successful in building the new Slovak state. The objective of the programme of Robert Fico's government and of the governing party (Smer) was to put an end to the harsh reform process launched by the Dzurinda cabinet. Most previous reforms, however, except in healthcare, survived (Mikloš 2008). The incoming government relinquished the flat-rate personal income tax scheme, on equity and tax policy grounds, but in other regards it retained, albeit in a softened form, the main economic policy and external relations directions set by the preceding centreright government. The process of euro adoption was one of the projects that were inherited from the previous administration and continued. The NBS made very clear in its cost-benefit analysis

\footnotetext{
${ }^{14}$ Thus, this was the period in which the Slovak decision-makers intended to fulfil - keeping, as it were, the government's momentum gained during the catching of the train of EU accession - the obligation to adopt the single currency at the first possible moment. Official documents refer to it as national endeavour in the face of regional competition, in which Slovakia was successful: of the Visegrad group, the direct point of reference both for society and for the Slovak political class, Slovakia was the first to be admitted to the euro area. Little did Slovak policymakers know during the 2003-2005 pre-intervention phase that not only would Slovakia precede its peers by a year or two, but the others would not even have a target date a decade after Slovakia's entry.
} 
that the euro adoption, on balance, would have a significantly positive output effect (Šuster 2006).

Even before the currency changeover, the EA had accounted for four-fifth of the Slovakia's foreign trade turnover; thus, one of the greatest benefits of the single currency was the reduction of transaction costs and the elimination of the exchange rate risk vis-à-vis the main trading and financial partners. These benefits are expected to be above average for small and medium-sized enterprises (SMEs): reduced transaction costs are an important consideration for businesses in weighing the pros and cons of entering the external market. EA membership also reduces the cost of capital, households and the SME sector benefit more from this factor than the large corporations. It was not considered at the time but later on it became an often-cited counterargument that the introduction of the euro would make credit too inexpensive, inducing a borrowing frenzy. In fact, the Slovak expectation was that better loan conditions should stimulate investment; the investment ratio of the Slovak economy was rather low at the time. ${ }^{15}$ The parallel decline in transaction costs and exchange rate risk attracted FDI inflows. Setting prices in the same currency boosts competition, and thus, benefits consumers.

The central bank analysis also touched upon the most frequently cited argument against the long-term exchange rate fixing and the irrevocable abandonment of the national currency: the loss of independent monetary policy (to be understood as central bank's interest rate policy). In a currency union, the Central Bank of a member state can no longer respond to an external shock by adjusting its own interest rates in order to stabilise the price and output level. The interest rate decision of the currency union's central bank (ECB) may not always be adequate for any given member state. The resulting losses should be therefore added to the costs of the changeover. In this regard, however, the national bank document pointed out that the effectiveness of Slovak monetary policy was limited as it was. ${ }^{16}$ In an environment of deregulated capital flows, the national bank was unable to stabilise the exchange rate of the koruna, the price level and the real economy simultaneously. The exchange rate of the koruna was driven by various external impulses, mainly from neighbouring countries, and "the exchange rate is often rather a source of shocks for the economy than their absorber" (Šuster op. cit., p. 9). ${ }^{17}$

These lessons may also be important for the countries that retained their national currencies, given the limited size of the financial markets in all Visegrad countries. The currencies of small

\footnotetext{
${ }^{15}$ Over a twenty-year horizon, the additional growth effect of Slovakia's EA membership was projected to be in the range of $7-20 \%$ of GDP minus the one-off administrative costs of the currency changeover, estimated at $0.3 \%$ of GDP in the document referenced above (Šuster 2006). In contrast with the positive effect on the economy as a whole, some sectors were going to assume significant burdens; for example, banks were to lose some forex transactions. The greatest challenge, however, would be faced - as always - by society: people would have to learn new prices.

${ }^{16}$ The NBS study also refers to the aspect of endogeneity: the lack of a national monetary policy within the EA will lose significance over time as the business cycles of the member states will become increasingly synchronised through strengthened intra-sectoral relations and intensification of trade with the EA partners. The author correctly notes that it would be a mistake to assume - and hence, use as an argument against the currency union - that the mediocre business-cycle synchronisation of the candidate countries would remain the same over the medium or long-term. Even some asynchronous periods resulted from the important reforms and stabilisation measures implemented by the transition countries before they entered the EU but it would be unreasonable to assume the recurrence of shocks of this magnitude. Eventually, the cost associated with the loss of monetary policy independence was forecast as $0.04 \%$ of GDP, a negligible amount compared to the positive items (Šuster op. cit.: 9).

${ }^{17}$ Borghijs - Kujis (2004) drew a similar conclusion from the processes of the region.
} 
and open economies are particularly exposed to shocks caused by economic, natural or political events, which may result in volatile fluctuations in the currency exchange rate that are hard and costly - to tackle by the monetary authorities. By contrast, the EA, owing to its formidable size, is rather immune to speculative attacks or random impacts.

In consideration of the clear and significant economic benefits and the fact that Slovakia was in ERM II by the time of the political turnover of 2006 and had already completed the lion's share of the macroeconomic stabilisation tasks required for meeting the Maastricht criteria, the Fico government continued the project until the adoption of the euro. The technical changeover was carried out smoothly.

The euro adoption, as mentioned, coincided with the outbreak of the global financial crisis. The depth of the downturn experienced by the extremely open Slovak economy surpassed the European average in 2009. On the other hand, the upswing following the crisis year was also far more dynamic than the European average, owing to the foreign enterprises - mainly manufacturers operating in Slovakia. As expected, synchronisation with the EA countries, in particular with the business-cycle of Germany, improved further. As a result, however, the 2011-2012 turmoil of the EA temporarily affected the otherwise robust recovery cycle of the Slovakian economy as well.

Two findings of the IMF country report issued after the crisis years deserve special attention (IMF 2012). Firstly, Slovakia's external competitiveness was preserved even in the period following its accession to theEA. Although the national currency was abandoned at a strong exchange rate, since the irrevocable fixing had preceded the outbreak of the crisis, this circumstance did not play a material role in external trade thanks to Slovakia's considerable openness to both exports and imports. In fact, the IMF report stated that the Slovak recovery process was largely driven by exports. ${ }^{18}$ It was, however, also noted - albeit guardedly - that there was a loss of confidence in the government's commitment to fiscal discipline. Indeed, this was reflected in the sharp increase in credit default swap (CDS) spreads while the Czech CDS spread remained unchanged; at the end of 2011 the Slovak spread jumped to a range of 200300 bps from around 100 bps. It should be added, however, that these values were far better than the Hungarian sovereign spread of over $600 \mathrm{bps}$ at that time.

Compared to the Dzurinda government - which had announced the modernisation turnaround and to that end, did not hesitate to undertake unpopular measures - the Fico government followed different objectives and values indeed. The general public perceived both the weakening of the commitment to the European project and the differences in values. By then, however, the behaviour of the Fico governments - and their penchant for populist elements were no longer seen unique or extreme in the region.

We can also draw a general conclusion from the government policies of other new EU member states after their accession to the EU: with the admission criteria fulfilled, the

\footnotetext{
${ }^{18}$ The preservation of external competitiveness and the years of a consistent, robust increase in labour productivity are closely related to the sharp increase in foreign direct investment starting from the beginning of the 2000s. For Slovakia, this was the era of the 'Tatra Tiger' but other countries of the region also saw a robust influx of capital (along with a deterioration in the current account). An ECB's study on our region highlighted significant divergences between countries in terms of current account deficit; yet the sizeable current account deficits recorded in the Visegrad countries - especially, in Slovakia - were not considered excessively high because they were fully covered by FDI inflows (Ca'zorzi et al. 2009). In theory, FDI stock may also contract but certainly this did not take place in the V4 region; in fact, Slovakia gained a security advantage in an environment of abruptly escalating business uncertainties by joining the euro area.
} 
Table 2. Support for the euro in new Member States (\% of respondents)

\begin{tabular}{|c|c|c|c|c|c|c|c|c|}
\hline & \multicolumn{2}{|c|}{2006} & \multicolumn{2}{|c|}{2010} & \multicolumn{2}{|c|}{2015} & \multicolumn{2}{|c|}{$\begin{array}{c}2020 \text { (May-June) } \\
\text { (B: 2018) }\end{array}$} \\
\hline & For & Against & For & Against & For & Against & For & Against \\
\hline \multicolumn{9}{|c|}{ Bulgaria } \\
\hline$A$ & - & - & 46.1 & 41.6 & 42.0 & 46.0 & 42.0 & 49.0 \\
\hline B & - & - & 72.0 & 18.0 & 51.0 & 31.0 & 48.0 & 36.0 \\
\hline \multicolumn{9}{|c|}{ Croatia } \\
\hline$A$ & - & - & - & - & 42.0 & 47.0 & 53.0 & 41.0 \\
\hline B & - & - & - & - & 46.0 & 40.0 & 57.0 & 29.0 \\
\hline \multicolumn{9}{|c|}{ Czechia } \\
\hline$A$ & 44.3 & 39.9 & 36.1 & 59.4 & 30.0 & 63.0 & 36.0 & 57.0 \\
\hline B & - & - & 83.0 & 7.0 & 54.0 & 36.0 & 52.0 & 37.0 \\
\hline \multicolumn{9}{|c|}{ Hungary } \\
\hline A & 40.7 & 40.6 & 41.8 & 36.6 & 53.0 & 38.0 & 60.0 & 30.0 \\
\hline B & - & - & 86.0 & 8.0 & 56.0 & 30.0 & 58.0 & 22.0 \\
\hline \multicolumn{9}{|c|}{ Poland } \\
\hline A & 43.0 & 39.1 & 36.4 & 50.3 & 39.0 & 53.0 & 47.0 & 46.0 \\
\hline B & - & - & 78.0 & 13.0 & 58.0 & 28.0 & 54.0 & 31.0 \\
\hline \multicolumn{9}{|c|}{ Romania } \\
\hline A & - & - & 58.3 & 32.1 & 59.0 & 32.0 & 53.0 & 27.0 \\
\hline B & - & - & 84.0 & 5.0 & 40.0 & 42.0 & 50.0 & 34.0 \\
\hline
\end{tabular}

Source: A-B: Flash Eurobarometer №. 191, №. 307, №. 418, No. 487; C: AHK (Auslandshandelskammer) Survey $2018,2015,2010 .^{19}$

willingness to comply with the EU norms tends to wane. The worst backsliding can be observed in the countries where the euro adoption project had not commenced yet, and thus, it did not extend the period of external pressure-driven compliance (Györffy 2009).

National pride over the country's success in earning EA membership so fast was cooled down by the recognition that the rights and benefits of the EA, as is the case with any other institution, come hand in hand with obligations and costs. In response to the Greek crisis, the

\footnotetext{
${ }^{19}$ On the Slovak sample, the euro was thought to be 'a good thing' by $79 \%$ and ' $a$ bad thing' by $9 \%$ of the respondents. In both wording versions, support for the euro was higher in Slovakia than in the EA and in the total EU on average. The situation is completely different in the neighbouring Czech Republic, where - despite (or because of) physical and logistical proximity to the German economy - people negatively associate the euro with a 'German accent', the adoption of the euro is not a popular idea, and government communications all but reinforce the majority sentiment.
} 
EA members set up a temporary assistance fund (European Financial Stability Facility - EFSF) in 2010; Slovakia, obviously, was also required to contribute. But the very thought of providing financial assistance to others met with strong resistance in public opinion: while the continuous financial assistance entailed by the EU membership was taken for granted by the Slovak population (and in the CEE region, in general) in view of the country's relatively low level of development, it was unprepared to contribute to bailing out the older Member States.

The numbers included in Table 2 are the aggregated numbers of responses for the question "Do you think the introduction of the euro would have positive or negative consequences for you personally?" The survey was made among the residents and the values can be seen in rows " $A$ ". In rows " $B$ " managers' opinions are aggregated from the respective countries concerning support to the introduction of euro. The percentage of responses indicated in the table includes "very positive" plus "rather positive" as 'for'; while "very negative" plus "rather negative" as 'against'. Sum of 'for' and 'against' is less than $100 \%$ because of "don't know" or "no opinion" options.

The troubles of Greece did not spark a great deal of compassion in Slovakia, and opinion leaders rightfully pointed out that the financial well-being of the Greek population ranked at around $90 \%$ of the EU average at the onset of the country's financial distress, whereas Slovakia's relative level of development was barely above $60 \%$ (identical with that of Poland and Hungary). This issue led to a government crisis and, ultimately, to the 2012 re-election of Fico who had been removed from office at the 2010 general elections. ${ }^{20}$ In Slovakia, the population's support for the euro was consistent with the changes in general public sentiment. The support should be crucial for policy makers in the period preceding the euro accession; afterwards - when nothing is at stake any longer - it simply becomes a sentiment indicator. In any event, support for the euro considerably exceeds the average values of the EU member states and of the EA, although this support temporarily abated in Slovakia, as well, during the turmoil in EA.

The financial crisis originated from outside of the EU in 2007 and it initially did not curb the attraction to European integration; there was even a moment in 2008 when the government of Iceland considered EU membership as a way out of the crisis. In addition, the European Union's participation in hammering out a bailout package for Hungary also sent a message to the policymakers and opinion leaders at the eastern and southern periphery of the EU: despite legal constraints, the EU membership entailed certain bailout options. This should be especially true to the EA members.

However, the protracted Greek crisis and the indecisive handling thereof undermined the strong pro-EU and pro-euro sentiments in the new member states. The 'wait-and-see' tactic was elevated to the level of government strategy in countries that had not committed to a clear and unambiguous euro adoption date until 2008. The financial crisis did not cause profound changes in the monetary cost-benefit calculations: the one-off costs of euro adoption would not have

\footnotetext{
${ }^{20}$ A multi-party coalition was set up for the 2010 general election, and the coalition succeeded in replacing Fico. Headed by Iveta Radičová, the government dragged its feet regarding the national contribution to the EFSF and its successor, the European Stabilisation Mechanism (ESM), even though it was under enormous external pressure due to the consensual decision rules of the funds. Of all euro area Member States, Slovakia was the last to vote on the measure, but the government's motion was rejected by Parliament in October 2011, which led to a no-confidence vote, new elections called for March 2012 and the fall of the Radičová government. The new Slovak government resolved the stalemate in such a way that, while it refused to contribute to the credit facility for Greece, it undertook a guarantee of EUR 7.73 billion under the EFSF and EUR 5.77 billion under the ESM which, combined, corresponded to $20 \%$ of Slovak GDP (Šuster 2014). Slovakia suffered no financial losses from the guarantee commitment.
} 
been higher after 2008 than those faced by the early adopters, and the long-term socio-economic benefits were unlikely to decrease. The financial crisis, however, eroded the social and political support for the westernisation process as a whole. ${ }^{21}$

\section{DOING BUSINESS IN CEE WITH AND WITHOUT THE EURO}

\subsection{Business use of the euro: a neglected aspect of the study of monetary sovereignty}

Theoretical studies dedicated to the subject of euro adoption do not tend to dwell on the competitiveness of the entrants, save for referring to the country's pre-entry macroeconomic position as a circumstance that either eased or hindered the changeover, or may warn the candidates against fixing the currency at a strong exchange rate unless it is warranted by productivity and general business efficiency. ${ }^{22}$ Yet, currency is a key factor in business calculations. According to the surveys conducted before the changeover, Slovakian businesses were quite aware of both the expected problems and the potential gains; most of them (especially SMEs) believed that the changeover would benefit their growth and especially exports.

As it happens, however, the changeover coincided with the global financial crisis, and therefore, the practical consequences of the entry are extremely hard to distinguish from the effects of changes attributable to other reasons. As early as December 2008, industrial output dropped by $16 \%$ in Slovakia, and in the following year - when Slovakia was already a member of the EA - exports fell by $30 \%$. This might reflect the detrimental business consequences of the fixed exchange rate, especially compared to the drastically weakening exchange rates of other three Visegrad countries. Yet, compared to the producers of countries with a floating exchange rate regime, factual data did not show a relative deterioration in the position of Slovak firms. The price of materials and parts imported during the fast-paced crisis dropped faster than the price of exported goods, and the improving terms of trade mitigated the profit loss of the Slovak firms. The increase in local wages did not affect the production and investment decisions. This is because they were based on the analysis of a broader range of risks rather than the data of the hectic transitional year. Countries with floating rates faced yet another risk factor arising from the volatility of the national currencies. ${ }^{23}$

\footnotetext{
${ }^{21}$ This view became prevalent after the events of 2012 in Europe, as confirmed by a volume of studies on the latest position of the V4 governments on EA accession: as indicated by phrases like 'better preparedness', 'reaching a broader societal and political consensus', playing for time had become the strategic approach taken by pre-ins (Gostyńska et al. 2014).

${ }^{22}$ As Lalinský (2010) pointed out in his competitiveness study prepared shortly after the euro adoption, the 2003 and 2005 annual reports of the Slovak Central Bank and Ministry of Finance were laconic in this regard: the relevant references are limited to the business risks arising from the elimination of the Slovak koruna at an overly strong exchange rate, or to the business benefits stemming from the reduction of transaction costs and the mitigation of the exchange rate risk.

${ }^{23}$ The restraint on the investment projects of multinational companies at the time was the drastic decline in demand; in addition, the volatility of exchange rates generated by the crisis was also detrimental to investment plans. Lalinský found that in this respect, the volatile changes observed in the exchange rates of the floating rate countries may have had (especially on a longer horizon) a negative rather than a positive impact on corporate competitiveness in the countries concerned (Lalinský op. cit.: 30).
} 
Thus, the expected loss of price competitiveness failed to materialise; in fact, Slovakia bounced back from the double crisis ('Lehman' and 'Eurozone') as fast as its peers. A key factor in this positive turn of events was the rapid increase in productivity, which was also evident relative to the Czech Republic, a natural benchmark for Slovakia.

\subsection{The experiences and lessons of Slovakia's early entry}

Michal Mejstrík (2016) observed that in the years after the EU accession, the wage increase was surprisingly fast (in the Czech Republic and also elsewhere), especially compared to the rate of productivity growth; yet productivity accelerated the most in Slovakia, where the residuals of the obsolete Slovak industry were replaced by highly productive car manufacturers (Mejstřík op. cit: 104). The same author identified the clear primacy of political considerations in the official Czech approach to the euro.

Data indeed indicate that the outstanding rate of Slovak productivity growth did not generate an increase in ULC; at the end of the decade the ULC still remained below the level of 2000, which may partly explain Slovakia's ability to preserve external competitiveness even in the face of the revaluations of the SKK and the adoption of the euro. ${ }^{24}$ There is still a need to explain the growth rate of Slovak productivity because, if we assumed that the fast improvement in the national average is simply attributed to the increased share of the highly productive FDI sector while the efficiency level of the other half of the economy (the SME sector) remains the same, this would be manifested in imbalances, such as increasing regional disparities or a rising number of SME bankruptcies.

Income disparities between the regions preferred by foreign direct investment and more remote areas exacerbated indeed. The efficiency of the Slovak SME sector, however, also improved significantly, especially in comparison to Hungarian data. ${ }^{25}$ This may indicate that the SME sector effectively reaped benefits from the euro changeover, but it could also point to other reasons: for example, the medium-sized Slovak companies may have integrated more successfully into the value chains built by large corporations than the Hungarian firms, or they may have utilised EU funds more efficiently.

An OECD survey on Slovakia's integration in global value chains provides a number of useful clues to the case (Giorno 2019). Although Slovak productivity decelerated in the period following 2009 - which was, in fact, consistent with the regional and European trends - it still surpassed the regional average. It is also true, however, that Slovakia (just like Hungary) was unable to generate a meaningful upward shift in domestic value added from a level that was not very high in the first place. The productivity of the micro-, small- and medium-sized enterprises falls considerably short of the productivity of large corporations in Slovakia as well, although the productivity gap is far smaller at companies with 10-19 or 20-49 employees than that seen in the Hungarian economy (Giorno op. cit., p. 18).

\footnotetext{
${ }^{24}$ Corporate surveys provide some guidance as to the other reasons that may be at play: among the macroeconomic factors relevant to the future competitiveness of companies, euro adoption was ranked only third by the Slovak company managers, after infrastructure and energy costs (Lalinský op. cit.:.34).

${ }^{25}$ As regards real ULC, the gap between the Hungarian and the Slovak (and also the Czech and Polish) indicators widened after 2009, reflecting the fact that in Hungary, the general wage increase of the region was not accompanied by substantive productivity growth for years (IMF 2017).
} 
In the Slovak case, geographic location appears to have the strongest explanatory power in corporate-level productivity: an extremely strong industrial/commercial agglomeration effect can be perceived around Bratislava, whereas only a fraction of the modernisation capital reached the severely underdeveloped eastern parts of the country. In this case, therefore, the sustainability of productivity growth does not hinge on the currency system but much rather on regional development, infrastructural, training and labour market factors.

Did, then, Slovakia's adoption of the euro bring about a substantive improvement in export performance at the level of the national economy, in particular, among SMEs? Tibor Lalinský and Jaanika Meriküll attempted to find an answer to this question by examining the Slovak and Estonian data (Lalinský - Meriküll 2018). Both countries had been open and, in terms of trade, strongly euro-oriented even before joining the currency area (which, in Estonia's case, was January 2011) but the obvious hypothesis of the authors was a further increase in trade flows to and from the EA countries. ${ }^{26}$ It was also a logical assumption that Slovak business life benefited more from the adoption of the euro as the changeover eliminated the exchange rate risks in the EA markets. This is because the Slovak koruna had followed a floating - albeit, somewhat managed - exchange rate regime until Slovakia's accession, whereas the Estonian kroon was pegged hard to the Deutsche mark from 1992 and to the euro from 2002; thus, the Estonian firms did not have to face an exchange rate risk even before the euro adoption. Moreover, as the above-mentioned study of the Slovak central bank noted, the adoption of the euro adoption was more likely to facilitate the exports of smaller-sized firms. ${ }^{27}$

Firm-level sales indicate that, in the case of the manufacturing sector, the currency reform strongly supported external trade indeed in the period of 2006-2011 in Slovakia and 2008-2013 in Estonia. Smaller Slovak firms (in the category of 20-49 employees) entered the new external markets at a high rate, although it should be noted that the volume of exports increased in all firm size categories. Slovak data clearly demonstrate the strong impact of the export growth stemming from the adoption of the euro (as a result of the changeover, exports to the EA rose by $14 \%$ ); Estonian data, on the other hand, are more modest (op. cit., p. 34). This is where the preaccession exchange rate regimes of the two countries made a difference: thanks to the Estonia's currency board arrangement, Estonian firms had been able to enjoy exemption from the exchange rate volatility vis-à-vis the EA far before the adoption of the euro. In other words, some of the positive effects had already existed and exerted their influence (except the reduction of transaction costs). The paper concludes that the "results of the survey are encouraging for small open economies with floating exchange rates that are planning to join the euro area or any other currency union. If the reduction in trade costs is substantial, it can lead to a substantial increase in trade". (op. cit., p. 34).

In view of the SME sector's important contribution to employment and overarching significance in other Visegrad countries, further research is needed to examine the extent to which the choice of a currency regime (fixed or fully floating exchange rates) and changes in the level of interest rates determine the export capacities and general competitiveness of the firms

\footnotetext{
${ }^{26}$ However, there were significant initial differences between the two countries in this regard: while $90 \%$ of Slovakia's trade with the euro area countries was conducted in euros in 2008 , the corresponding Estonian value was only $50 \%$ in 2010 (Lalinský - Meriküll, op.cit., p. 6). Another important difference is the exchange rate regime, which was floating in Slovakia and strictly pegged in Estonia.

${ }^{27}$ This is also the conclusion of the study published by (Esteve - Pérez et al. 2011).
} 
concerned. Hereby, it is important to revisit the microeconomic aspect and look at the spontaneous euroization of countries outside the EA, an aspect rather overlooked in the macroeconomic literature on currency choices (see sub-chapter 4.2).

\section{HAS IT PAID OFF TO ADOPT THE EURO? THE BALANCE OF A DECADE BETWEEN TWO CRISES}

\subsection{Eurozone membership: a stabilizing factor in turbulent times}

As any significant economic change, a currency changeover exerts its impact over the long term, and due to obvious endogeneity, the constantly changing impact factors may not be separated with certainty. Model calculations were prepared both before the decision and after the changes. After Slovakia's EA accession, a two-country dynamic stochastic general equilibrium (DSGE) model was built to estimate the long-run balance between the main benefit (i.e., foreign trade gain) and the main cost (loss of the central bank's monetary policy independence) in a counterfactual analysis: contrasting the actual trajectory against a growth path that would have evolved if Slovakia had adopted the euro in 1999 instead of 2009 (Zeman 2012). ${ }^{28}$

The policy difference of the real-life case and the counterfactual is an earlier loss of an independent interest rate policy in the latter case, and the issue at stake is having an output gap i.e., the gap between potential and actual output - without national interest rate policy. As expected, the model claims that cyclical swings caused by domestic demand shocks or external shocks are more volatile without the independently applicable interest rate instrument, which results in macroeconomic losses. On the other hand, the positive effects include, in particular, the increase in trade and welfare prompted by the lower import prices. Losses are expected to be more significant in the first few years of the hypothetical membership as the volatility caused by the shock would abate only gradually; but subsequently, with economic stabilisation and a closer covariance with the EA, the lack of an independent monetary policy becomes less of a problem. Overall, the changeover leads to a $0.62 \%$ gain of steady-state consumption which, according to the model, is the net result of a $0.7 \%$ gain caused by lower transaction costs and a $0.08 \%$ loss produced by the higher volatility of economic fundamentals (Zeman op. cit., p. 16).

The analysis published by the NBS for the 10th anniversary of the euro adoption confirms that the lower transaction costs resulting from the use of the single currency contributed to an increase in trade with the EA member states both in terms of exports and imports, which accelerated the growth of the domestic economy. In addition, concerns about rising consumer prices proved to be unjustified. That notwithstanding, the actual gain from the adoption of the euro fell somewhat short of expectations but this can be mostly attributed to the external events, such as the global economic crisis and the protracted crisis of the Eurozone, that were detrimental to the development of the global economy as a whole (Lalinský - Šuster 2018).

The improvement in productivity is especially noteworthy. It can also be seen that several important parameters of the Slovak economy, such as its debt-to-GDP ratio (which is a significant factor in the economy's exposure to external shocks), remained unscathed from the interruptions or trend reversals during this momentous period.

\footnotetext{
${ }^{28}$ Similar calculations have been made for the British and the Swedish economy (see Zeman op. cit., pp. 4-5).
} 
Using the synthetic control method (SCM), researchers of the OECD explored the effects of the euro adoption on Slovakia's economic performance after the first five years of Slovakia's accession to the EA (Žúdel - Melioris 2016). This method compares the actual performance of an economy to a synthetic counterfactual path; in this case, it compares the actual Slovak data to the data of a 'synthetic Slovakia' constructed from the data of the Czech Republic, Poland, Hungary and Romania (i.e., the four countries with a floating exchange rate regime). Consistent with the usual expectations, the calculations demonstrated that Slovakia's annual output data would have been temporarily better off by $2 \%$ during the 2009 recession had the exchange rate regime remained flexible. Long-term results, however, are quite different. On a longer horizon lasting until 2011, Slovakia gained $10 \%$ of GDP per capita by the adoption of the euro. However, in contrast with the data of the synthetic state, the bulk of this gain (around 7\%) occurred even before the accession due to the combined effect of the pre-intervention period and external expectations, although the upside effects were still continuously present in the years following 2009 (Žúdel - Melioris op. cit., p. 10).

Data derived from the synthetic control method are fairly robust but, as all other simulations of this or any other kind, they are exposed to the effects of random events or non-economic developments during the review period or 'noises' during the development of the countries under review. However, these and subsequent model calculations reconfirm the expectations on the basis of which the authorities made their decisions in the period of 2003-2006. It was reliance on these expectations that ensured the survival of the political commitment to the euro adoption even after the change in the country's political stance. The actual growth rate reconfirmed the approximate size of the growth gain fairly well, although the deterioration in the global economic environment led to a deceleration that appeared persistent (as everywhere else in the region).

The decade after the financial crisis turned out to be, on the whole, successful for the region in terms of economic growth, and thus, gradual convergence towards the European per capita output average. Institutionally, half of the countries of the region became EA members, with all the additional implicit and explicit financial protection that the Eurozone grants. Even a cursory glance at the figure indicates that staying outside the EA would not exclude an economy from the growth club of Europe and, similarly, having the euro as legal tender will not necessarily guarantee above-average growth of GDP and exports. Nor would retaining national currency exclude a country from the club of good sovereign risk, see the Czech case although it is noteworthy that all EA-members of the region have A+ or higher. Yet, Poland, a non-EA country, tops the regional growth league table of the period covered, followed by Romania and Slovakia; Croatia (non-EA) and Slovenia, and Latvia is at the bottom - there is no clear picture.

What data of Table 3 expose is a variety of country performances throughout the decade covered in terms of output and, not discussed here so far in detail, institutional-political aspects, such as the case with corruption, rule of law, and efficiency of checks and balances within the state. Column 5 of the table reflects how diverse is the case in the region according to the widely used and accepted measures of transparency by Transparency International (TI). What is behind the episodes of performance divergences and institutional varieties, including membership in EA, are varieties of policy reactions to crisis; that has been the lesson since the transition crisis of the 1990s, as well as of the financial crisis of 2008, and probably of the COVID crisis of 2020, too. 
Table 3. Performance data of CEE countries

\begin{tabular}{|c|c|c|c|c|c|c|c|}
\hline Country & $\begin{array}{c}1 \\
\text { GDP average } \\
\text { growth rate } \\
\text { 2009-2019 }\end{array}$ & $\begin{array}{c}2 \\
\text { Export } \\
\text { growth rate } \\
2009-2019\end{array}$ & $\begin{array}{c}3 \\
\text { Labour } \\
\text { productivity } \\
\text { growth } \\
2009-2019\end{array}$ & $\begin{array}{c}4 \\
\text { GDP/capita PPS, \% } \\
\text { EA }=100 \\
2018\end{array}$ & $\begin{array}{c}5 \\
\\
\text { Transparency } \\
\text { score (CPI) } \\
2019\end{array}$ & $\begin{array}{c}\text { Bertelsmann } \\
\text { Foundation } \\
\text { Sustainable } \\
\text { Governance Index } \\
\text { out of } 100\end{array}$ & $\begin{array}{c}6 \\
\text { Sovereign risk rating, } \\
\text { S\&P, } 2020\end{array}$ \\
\hline Bulgaria & 1.8 & 4.5 & 2.5 & 53 & 43 & 44 & BBB \\
\hline Croatia & 0.2 & 3.2 & 0.7 & 65 & 47 & 50 & BBB- \\
\hline Czechia & 1.6 & 4.4 & 1.2 & 92 & 56 & 62 & AA- \\
\hline Hungary & 1.8 & 4.1 & 0.4 & 73 & 44 & 35 & BBB \\
\hline Poland & 3.5 & 6.2 & 3.2 & 73 & 58 & 53 & A- \\
\hline Romania & 2.3 & 7.9 & 3.0 & 69 & 44 & 53 & BBB- \\
\hline Estonia* & 1.9 & 4.4 & 1.7 & 84 & 74 & 79 & $A A-$ \\
\hline Latvia* & 0.9 & 4.2 & 2.3 & 69 & 56 & 70 & $\mathrm{~A}+$ \\
\hline Lithuania* & 1.7 & 6.1 & 1.9 & 82 & 60 & 62 & $\mathrm{~A}+$ \\
\hline Slovakia* & 2.2 & 4.5 & 1.4 & 74 & 50 & 53 & $\mathrm{~A}+$ \\
\hline Slovenia* & 0.9 & 3.6 & 0.5 & 88 & 60 & 62 & AA- \\
\hline
\end{tabular}

Source: ECB Annual Report 2019, S\&P, Eurostat, Transparency International.

Note: V4 countries in italic and EA members with asterisk. 


\subsection{Crises change the cost/benefit calculations of the euro adoption in CEE}

Reaction of the national authorities to the subprime crisis was certainly diverse. The fact that the Slovak economy got on with the critical year of 2009 without major damages and managed to maintain its growth gain relative to the European average without notable swings is partly explained by the antecedents outlined above. Before long, the political decision to commit to the Maastricht criteria put an end to the era of the twin deficit; and, thanks to the firm commitment to meeting the criteria, Slovakia entered the global financial crisis with a moderate, easy-tomanage external indebtedness.

The long-term development of the Slovak economy, as general, depends on a multitude of factors; the EA membership does not guarantee sustainable growth in itself. The case presented is more likely to reconfirm the argument that the adoption of the single currency, given persistent commitment to the integration process, can be implemented successfully with affordable changeover sacrifices, the discipline of economic policy can be maintained, the probability of policy backsliding can be minimised, and the costly forced adjustments can be avoided. $^{29}$

Given the limited number of former planned economies in and outside EA, it requires a great deal of caution to draw general conclusions. Few economic arguments support the long-term preservation of the national currency in small open economies: with the small size and specificities of the Slovak, Estonian and Slovenian economy, it would have been hard to justify maintaining the national currency for too long or systematic postpone the fulfilment of the EMU commitments. Understanding the limitations of a small economy, the successive governments of these countries considered the euro adoption as a technical necessity but also as a

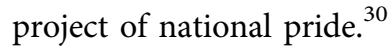

This is a completely different approach than that taken by long-standing pre-ins. In Poland, Hungary and Czechia political considerations were mostly raised juxtaposed with economicfinancial arguments. The issues of the assumed institutional deficiency of the EA and the

\footnotetext{
${ }^{29}$ In the Hungarian debates, the case of Slovakia is often cited as a positive example where the euro contributed to the country's economic successes. Those who do not accept the euro as a successful European currency are less unimpressed by these successes. One may claim that inflow of FDI was behind the growth performance rather the euro adoption. As we saw, in the first decade of its independent existence Slovakia stood out in the region with its modest ability to attract capital; this was only turned around by the reforms implemented under the Dzurinda government that broke the upward spiral of general government deficit which, by the end of the 1990s, had reached alarming levels. Meeting the Maastricht criteria had stabilised the general government even before the populist political turn around, and after 2006 the inherited - and retained - euro adoption project, in turn, protected the country from another fiscal backsliding. During the global crisis, Slovakia - already a member of EA - had more leeway to ease fiscal positions as opposed to Hungary where, in the lack of a similar disciplinary project, the state equilibrium had severely deteriorated before the crisis and subsequent governments were forced to bring austerity measures in 2008-2009, in a period of recession.

${ }^{30}$ Commitment to the Euro-Atlantic partnership has been dominant in Slovakia's public opinion and in the programmes of main political parties for a long time, although - as in any other European society in a similar position - the rejection of the European orientation is also present as a viral minority opinion. This is why the outcome of the parliamentary elections on 29 February 2020 bears such a great significance: the Slovak National Party (Slovenská Národná Strana), which is by no means an advocate for the European values, failed to meet the $5 \%$ electoral threshold, while People's Party - Our Slovakia (Ludová Strana Naše Slovensko) - the only party winning seats in Parliament that calls into question Slovakia's Euro-Atlantic integration - finished fourth with $8 \%$.
} 
arbitrariness of the admission criteria, as well as unpreparedness of the candidate country were put forward as professional counter-arguments in central bank publications, put against the principle of closer European integration labelled as 'politics'. By contrast, in drawing up a list of pros and cons, Slovakia and the Baltic entrants added the financial-economic arguments together with the motive of belonging to the inner circle of the EU ('politics') and contrasted the sum of all these against the one-off financial and socio-psychological costs of the changeover.

Reviewing these cases, we have found that - besides the admittedly arbitrary values of the accession criteria and the tight schedule of the compliance process - the timing of the entry poses the greatest macroeconomic risk; that is, whether the accession takes place at a fortunate or unfortunate moment. Chance may play an important role in the market conditions and the exact rate of conversion when the irrevocable fixing takes place.

Based on the cases so far, the length of time elapsing between accession to the EU and joining the third stage of the EMU appears even as a more significant factor. From the evolution of Slovenia's economic policy process, we may conclude that the country's EA entry (in January 2007) was premature - too easy, as it were - and once the country found itself 'in', macroeconomic discipline began to slacken. In this regard, the timing of Slovakia's entry can be considered fortunate indeed, because it extended the duration of the consensual national project that had been aimed at earning membership in the EU. The rest of the Visegrad states missed their chance of an early euro entry in the wake of EU accession, which is more likely to increase later the political costs of the euro adoption while, for various reasons, the welfare gain entailed by the EA membership may turn out to be smaller than what could have been gained between 2005 and 2008.

An important insight gained from the literature dedicated to the Slovak case is the fact that monetary autonomy is rather formal in terms of interest-rate setting and exchange rate determination in the period preceding the euro adoption. Consequently, relinquishing independent monetary policy as a tool is not a very high price to pay; based on the data of Slovakia's actual macroeconomic path, the financial losses arising from the abandonment of its monetary policy were negligible, and are likely to remain marginal even for the existing pre-ins.

It is noteworthy that the sector of non-resident corporations benefited less from the gains entailed by the single European currency than smaller-sized resident companies. The effect of lower cost of funds and reduced transaction costs bears more relevance to the latter's growth prospects than this business segment tends to realise.

The governments of EA entrants perceive that, as users of the single European currency, they are now on an equal footing with the core countries in a series of essential issues. And this is also how they are perceived by the world. ${ }^{31}$ The Slovak monetary policymakers do not specifically view their participation in the internal decision-making forums of the EA as an advantage, they simply take it for granted; but it should be understood - especially seen by the non-EA decision makers - that this situation obviously puts pre-ins at a disadvantage. This is especially true in a period where essential reforms were implemented in the EA in response to the crisis. The monetary authorities of Slovakia are represented at the decisions whereas the Czech, Hungarian

\footnotetext{
${ }^{31}$ The nomenclature of the IMF's World Economic Outlook is rather telling: the 'advanced economies' category comprises the euro area (including Estonia, Latvia, Lithuania, Slovakia and Slovenia) and, as part of 'other advanced economies', the Czech Republic. Hungary is in the group of 'emerging and developing Europe' together with Bulgaria, Croatia, Poland and Romania (IMF 2019).
} 
and Polish officials are not. EA membership entails a certain ability to enforce a position; pre-ins are left out of this opportunity. The longer a country's euro zone accession drags on, the greater number of institutions and already approved principles must be put up with by the latecomer, and thus, the greater adjustment burden is imposed on the acceding country. It is also evident that by procrastinating with the accession process (and especially, by refusing to set a target date), business participants and policymakers lose an anchor which could have facilitated a smoother changeover down the road and helped prevent costly mistakes.

\section{ECONOMIC NATIONALISM, MONETARY SOVEREIGNTY, AND 'DEVELOPMENTAL STATE': ARE THERE SUCH OPTIONS IN CEE?}

Decision about the currency regime, as discussed above, is part of a much larger issue involving the nature and character of the country's policy stance. In 1990 when the political and economic system suddenly changed in the region, new governments embarked on the task of re-establishing market-based economy with a predominant privately-owned corporate sector, by bringing in FDI and privatizing state-owned firms. As a result, outdated structures were removed vigorously. Yet, the rapid takeover of the former state-owned flagship industries, major banks and insurance companies by foreign investors created political problems.

With this background, it is less surprising that protectionism and economic nationalism has resurfaced in the region. ${ }^{32}$ Two decades after the great transformation, already in the wake of the financial crisis of 2008, the supportive attitudes of some governments to foreign capital became rather opportunistic. It involved supporting the national insiders over foreigners in finance, energy and tourism, but also recruiting multinational firms to create jobs and upgrade export capacities. Granting direct subsidies, under the EU competition policy rules, became harder but currency depreciation seemed to remain a tool as an indirect support to exporters. As we will highlight here, exchange rate flexibility is, in fact, an inefficient policy instrument in an economy intensively integrated into trans-border production chains. Moreover, the floating nature of any currency of limited global size causes more handicap to businesses than intervention-minded politicians assume. Still retaining monetary policy independence for international competitiveness purposes is a rather popular concept in policy circles.

Proactive economy policy instincts received reinforcement out of the 2008 crisis. The financial crisis immediately weakened public trust in banks and finance, but also in market order in general. Crisis management mode always assumes enhanced state activism - this is, at least, one possible reaction to the increased level of uncertainty. Yet for the small, open economies, such as the Baltic states, another, and superior, strategy offered itself: getting better integrated into a large economic and policy integrations, the EU. The policy choices are not limited to choosing the right speed towards further integration. In Hungary, in particular, the interventionist government of Orbán that came to power right after the financial crisis, expressed

\footnotetext{
${ }^{32}$ For a description and analysis of the region, put into a context of 'dependent market economy' (DME) school of thought, and the spread of the tendency of financial and banking nationalism, see Piroska et al. (2020). The DME classification is contingent on such features of the countries concerned as offering cheap skilled labour and absorbing foreign technological transfer and FDI - that is, the characteristics of what has been termed here as 'EU-periphery' without further elaboration on the political-economic system.
} 
interest in non-conventional economic policy methods and development measures, with increased government control on economy and society, under a self-styled 'patriotic economic policy', moving toward a 'development state' concept. ${ }^{33}$

In the CEE and elsewhere, the reactivation of governments in economic and social issues does not seem to be a transitory phenomenon. First the government in Hungary, and later, in Poland initiated and institutionalised measures that put these countries apart from the majority of the EU member states in as much an emerging policy model, a sort of developmental statism, had been underpinned by intellectual and ideational strands. ${ }^{34}$ While analysts conclude that both Hungary and Poland have departed in various ways from the democratic and political mainstream of European values and best practices, Hungary's scores on various democracy and integrity indicators have steadily worsened, but for Poland, the picture is more mixed picture, with some indicators improving, other worsening over the decade (Hare 2020). This is otherwise also our reading of the data of Table 3 and other related sources.

Enhanced government activity, including nationalization of selected sectors and firms, and attempts to imitate pro-growth policies of the Asian emerging economies might be assumed as provoked by identified dangers of getting stuck in, as it were, middle-income trap. ${ }^{35}$ Certainly, the period between the two crises, that is 2008 through 2020, exposed the weaknesses and unsustainability of the former mainstream policy patterns in the CEE countries. Given several worrying social and economic trends, issues were raised such as: how to stop the brain-drain from the CEE region where the population declines and, unlike in other EU members, immigration is not regarded as a substitute for the missing labour force? How to move from the present level of mediocre complexity up in the GCVs when core partners happen to be found in the far-away countries? ${ }^{36}$

This is the context in which sovereignty issues, including monetary sovereignty, are best discussed. From a distance, the V4 countries may seem to have followed similar strategies of catching-up to more advanced European countries: financial support to R\&D, tax incentives for strategic firms, coupled with some efforts to promote the growth of local businesses. Yet, economic strategies differ, and monetary policy is an obvious example of how governments imagine the path to further prosperity. Slovakia joined the EA in 2009 as an "early bird" and seems to have benefitted from that move, while governments of other three Visegrad countries have not given up sovereign monetary policy. ${ }^{37}$

\footnotetext{
${ }^{33}$ The concept of the developmental state, as introduced by C. Johnson (1982), was originally applied to Japan, with characteristics including a long-term commitment to the developmental-oriented approach, state interventionism, and some kind of social consensus regarding the central role of state in development. For contemporary versions, see Ricz (2016). What actually influenced politicians in some CEE countries was the spectacular, even if transitory, growth performance of the BRICS countries right after the 2008 financial crisis in contrast with the advanced economies.

${ }^{34}$ The Polish and Hungarian cases, discussed together with that of Russia, are described by Bluhm - Varga (2019) as new economic nationalism combined with conservative developmental statism.

${ }^{35}$ The phenomenon of middle-income trap (MIT) as described by Garrett (2004) assume that growth rate at a particular level tends to remain lower than those of more advanced as well as less advanced countries. A number of observations support the assumption that such trap exists for moderately developed countries (Gill - Kharas 2015).

${ }^{36} \mathrm{CEE}$ 's involvement in intercontinental migration is expected to continue in the future, and is driven by demographic and economic catalysts, hence, to address all related issues and map trends, not only an economic perspective is required (Bite et al. 2020; Karácsony et al. 2020).

${ }^{37}$ We have analysed this aspect in more detail in Bod et al. (2020).
} 
Table 4. Indicators of euroization of banking and trade in the non-EA countries

\begin{tabular}{|l|c|c|c|c|}
\hline Country & $\begin{array}{c}\text { Euro-denominated } \\
\text { deposits as a \% } \\
\text { of total deposit, } \\
\text { Dec. 2019 }\end{array}$ & $\begin{array}{c}\text { Euro-denominated bank } \\
\text { loans as a \% } \\
\text { of total loans, } \\
\text { Dec. 2019 }\end{array}$ & $\begin{array}{c}\text { Share of euro in } \\
\text { total exports, } \\
\mathbf{2 0 1 0}\end{array}$ & $\begin{array}{c}\text { Share of euro in } \\
\text { total exports, } \\
\mathbf{2 0 1 9}\end{array}$ \\
\hline Bulgaria & 28.0 & 32.3 & 56.1 & 64.0 \\
\hline Czechia & 6.3 & 13.8 & 76.4 & 79.4 \\
\hline Croatia & 49.2 & 50.8 & $82.0 *$ & n.a. \\
\hline Hungary & 16.2 & 23.0 & 60.7 & 71.7 \\
\hline Poland & 7.9 & 9.8 & n.a. & n.a. \\
\hline Romania & 29.8 & 30.0 & 71.3 & 81.3 \\
\hline
\end{tabular}

Note: * year 2012 for Croatia.

Source: ECB 2020 (Table A9, A10, A11).

Maintaining the national currency is, first of all, motivated by political calculations. It could serve economic policy purposes if the national authorities had the capacity to take advantage of the exchange rate and/or interest rate as policy instruments. Yet, the embarrassingly high volatility of the exchange rate of floaters in difficult time, and the widespread use of the euro as parallel currency indicate that few if any benefits may accrue to authorities under the specific European conditions.

Taking currency volatility and spontaneous euroization (see related indicators in Table 4) as aspects that are important for the business and the general public alike, and that influences the ease of currency changeover, the "out-group" had evolved in rather different ways up to 2020.

The Czech authorities remained in a rather easy position to argue for "wait and see" as the rate of Czech koruna to Euro had been stable for many years with national saving predominantly in domestic currency, indicating trust in the koruna. The Czech economy is organically integrated into GVCs, with transactions mostly denominated in EUR, yet the euro had not assumed a serious position as a parallel currency.

The Polish situation was similar, although the zloty had not been as stable against the euro as the Czech koruna. Poland had a relative low level of euroization of savings and credit activities, thus policy actions of the central bank remained effective in the market.

Hungary is, however, in an intermediate situation. It had gone through a rough period in order to reduce the high share of non-domestic currencies in banking ("Swiss franc household debt debacle"), and is a moderately euroized economy, but the HUF exchange rate had been very volatile, and the inflation had been rather high and unstable.

The three other countries had become highly euroized, and thus, would benefit a lot from the adoption of the euro, and not much to lose from giving up monetary sovereignty that had been notional throughout the period leading to formal entry into ERM II. For Bulgaria and Croatia, the decision about euro adoption was a matter of fact as soon as entry conditions were met. The euro had played an important role also in the Romanian economy and daily life, and euroization 
had been particularly strengthened by the remittances of Romanians earning income in the EA countries, thus the de jure euroization is a logical conclusion of a long process.

\section{CONCLUSIONS}

A monetary policy regime change - here, adoption of the euro - involves two key dimensions that may strengthen or may, under other circumstances, undermine each other.

One is the dimension of economic and financial rationality and feasibility. Namely: under what conditions and when will adopting the common European currency pay-off for the country as a whole. The other dimension is political; it involves various internal and external stakeholders. One would have assumed that particular domestic political interests, government considerations and other par excellence political factors would gradually lose importance in the process of real and institutional convergence within the EU, and the increasingly positive cost/ benefit balance tilts the arguments in favour of a timely EA entry. Yet, the hoped-for convergence of the concerned member states had been repeatedly disturbed by episodes of divergence, particularly at times of crises and turbulences, weakening the compelling economic logic of euro adoption. Key stakeholders, meanwhile, had been influenced asymmetrically by the events, and what used to be a common understanding about the adoption of the euro as part of the grand European design became an issue for political decision. The financial crisis of 2008 weakened old certainties and broadened the imaginable options open for those in controlling position, hence the divergence in the official attitudes to the EA.

In the CEE region, Slovakia's euro changeover was a closed chapter when another crisis hit the region in 2020. We believe that Slovakia's way was successful; monetary pragmatism was also coupled and supported by nation-state building sentiments. Otherwise, in the years before the COVID crisis, the euro adoption issue seemed to be settled: three countries of the region (Bulgaria, Croatia, and somewhat later, Romania) had committed themselves to adopt the euro, while Czechia, Hungary and Poland maintained their "wait and see" position.

Still, the EA-entry process remained in limbo, and the domestic situations of the remaining nonEA countries differ. People and the business sector in Czechia have not shown much enthusiasm toward the euro, recognizing the relative stability of the Czech economy and the low volatility of the national currency. Poland is the biggest country and economy in the CEE region; therefore, its approach may influence the others. It is difficult, however, to see a consistent Polish government policy approach. The popular support of euro is higher in Poland than in Czechia, the zloty is moderately stable, and the Polish government had long followed the tactics or "wait and see".

The case of Hungary is peculiar. Even though the public and the businesses support the adoption of euro for reasons of high volatility of the national currency, among others, yet the government and especially the central bank had been strongly against the adoption of euro since 2010. The official Hungarian approach had been less motivated by clear monetary considerations than by the sovereignty arguments, claiming - not convincingly to us - that the independent monetary and exchange rate policies are efficient instruments of pro-growth goals.

The year 2020, however, upset the political and economics equations. Official disinterest in EA entry by the V3 governments may have been a low-key issue in the European policy-making circles in the post-2008 period but the threat that the Hungary/Poland tandem might veto critical common initiatives in the wake of the Corona-virus crisis alerted policy makers in the 
key European capitals. This particular veto threat was diffused in 2020 but the idiosyncrasy of the Eastern periphery of the EU was increasingly recognized as the issues of importance.

The political regime that emerged in Hungary after 2010 had gradually moved towards an active, developmental mode for a decade already before the COVID-crisis. The increasingly centralized state control, frequent interferences in the market mechanism and the peculiar quasi-fiscal operations of the MNB (posting income from the devaluation of the forint and using it to purchase real estates, precious pieces of arts, or to fund and finance institutions of higher education, among others) resemble the characteristics of a developmental state model. ${ }^{38}$ The logic and legal-institutional order of such regime is not compatible with the EA membership, and with the EU membership, in the first place.

Having concluded that macroeconomic and business considerations would strongly support the de jure euro changeover as soon as entry conditions could be met in the countries of the out-group, we also acknowledge that the 2020 crisis turned the political aspects even more complex. The crisis, as any crisis, tends to increase the activity of the government, even without prior ideational foundation of an active state up in arms to "defend national interests". When crisis looms on the horizon, a variety of competing policy options arise, as we have seen in the post-2008 period: one is to accelerate institutional convergence to the core, as in the case of the Baltic nations, and another is to keep distance from the problematic EU core (or, in extremes, to move away from the 'declining West').

These are pure political choices. Remaining in the realm of economic factors, we conclude that even a piecemeal enlargement of the EA that may seem marginal by the European standards - since Bulgaria, Croatia and Romania are economies of modest size - will cause material business consequences in the non-EA markets. First, the new entrants to the euro club are sizable economic partners for others in the CEE region. Also, the general public, another key stakeholder, may feel left behind in the V3 countries. The euro is popular among a large part of the voters in Hungary and Poland, and as a transaction currency it is used widely in business and everyday life. Having a fragile national currency is hardly a source of national pride, particularly with the rather inflationary Hungarian forint. The feeling of being left out of the 'club' is justified in as much as the EA has gained particular significance within the EU.

Currency variety of the CEE region, and of the supposedly more homogenous Visegrad group, indicates that the former transition countries do not seem to be in transit to the same destination, certainly not at the same speed. For all the countries concerned, the challenge is to move upward from the attained middle-income level and, in crisis, to protect themselves from further shocks. In many regards, the 2020 pandemic reshaped the state of affairs for all member states and underpinned the topicality of the dilemmas of euro adoption - an unfinished venture of the EU.

\section{ACKNOWLEDGEMENT}

The research was supported by the ÚNKP-20-3-II New National Excellence Program of the Ministry for Innovation and Technology from the source of the National Research Development and Innovation Fund.

\footnotetext{
${ }^{38}$ The developmental state model is proved to be efficient in the case of post-war Japan and in several other economies in East Asia. Its institutional foundation, however, cannot be applied in a European country, and it is certainly not in conformity with the standards and values of the EU.
} 


\section{REFERENCES}

AHK (2018): Investment Climate Survey Central \& Eastern Europe 2018. Results of the $13^{\text {th }}$ Investment Climate Survey of the German AHK Chamber Network in 15 Countries of Central \& Eastern Europe. https://www.ahkungarn.hu/infothek/publikationen/konjunkturbericht.

Bite, P. - Konczos Szombathelyi, M. - Vasa, L. (2020): The Concept of Labour Migration from the Perspective of Central and Eastern Europe. Economics and Sociology, 13(1): 197-216.

Blanchard, O. (2007): Adjustment within the Euro. The Difficult Case of Portugal. Portugal Economic Journal, 6(1): 1-21.

Bluhm, K. - Varga, M. (2019): Conservative Developmental Statism in East Central Europe and Russia. New Political Economy, 25(4): 642-659.

Bod, P. Á. - Pócsik, O. - Neszmélyi, Gy. I. (2020): Az euro és a szlovák gazdaság (The Euro and the Slovak Economy). Közgazdasági Szemle, 67(4): 321-351.

Bod, P. Á. - Pócsik, O. - Neszmélyi, G. I. (2021): Political and Policy Dilemmas of Euro Adoption in CEE Countries: What Next When Crisis Hits? European Policy Analysis. https://doi.org/10.1002/epa2.1111.

Borghijs, A. - Kuijs, L. (2004): Exchange Rates in Central Europe: A Blessing or a Curse. IMF Working Paper, No. WP/04/2.

Borowski, J. - Brzoza-Brzezina, M. - Fic, T. - Kot, A. - Mroczek, W. - Polafski, Z. - Rozkrut, M. Rubaszek, M. - Woreta, R. (2004): A Report on the Cost and Benefits of Poland's Adoption of the Euro. Narodowy Bank Polski, Warszawa, pp. 1-126. https://www.nbp.pl/en/publikacje/e_a/euro_adoption.pdf.

Ca'zorzi, M. - Chudik, A. - Dieppe, A. (2009): Current Account Benchmarks for Central and Eastern Europe - A Desperate Search? European Central Bank, Working Paper Series, No. 995.

Csajbók, A. - Csermely, Á. (2002): Adopting the Euro in Hungary: Expected Costs, Benefits and Timing. MNB Occasional Papers, No. 24.

Csillag, I. (2020): Beyond the First Glimpse (Analysis of the Economic Policy in Hungary from 1998). Acta Oeconomica, 70(3): 333-360.

Darvas, Zs. - Szapáry, Gy. (2008): Euro Area Enlargement and Euro Adoption Strategies. Economic Papers, No. 304. DG for Economic and Financial Affairs, European Commission.

ECB (2020): Convergence Report. www.ecb.europa.eu/pub/pdf/conrep/ecb.cr202006 9fefc8d4c0.en. pdf.

Engelberg, S. (1993): Czechoslovakia Breaks in Two, to Wide Regret. The New York Times, 1 January 1993. https://www.nytimes.com/1993/01/01/world/czechoslovakia-breaks-in-two-to-wide-regret.html.

Esteve-Pérez, S. - Gil-Pareja, S. - Llorca-Viveo, R. - Martínez-Serrano, J. A. (2011): The Impact of the Euro on Firm Export Behaviour: Does Firm Size Matter? Oxford Economic Papers, 63(2): 355-374.

Firdrmuc, J. - Wörgötter, A. (2013): Slovakia: The Consequences of Joining the Euro Area Before the Crisis for a Small Catching-up Economy. CESifo Forum, 14(1): 57-63.

Flash Eurobarometer - Surveys: Introduction of the Euro in the Member States that have not yet Adopted the Common Currency. No. 191 (September 2006), No. 307 (September 2010), No. 418 (April 2015), No. 487 (May - June 2020). https://ec.europa.eu/commfrontoffice/publicopinion/index.cfm/Survey/ getSurveyDetail/instruments/flash/yearFrom/1974/yearTo.

Fidrmuc, J. - Horvath, J. - Fidrmuc, J. (1999): The Stability of Monetary Unions: Lessons from the Breakup of Czechoslovakia. Journal of Comparative Economics, 27(4): 753-781.

Garret, G. (2004): Globalization’s Missing Middle. Foreign Affairs, 83(6): 84-96. 
Gill, I. S. - Kharas, H. (2015): The Middle-Income Trap Turns Ten. Policy Research Working Paper, No. 7403, World Bank Group.

Giorni, C. (2019): Increasing the Benefit of Slovakia's Integration in Global Value Chains. OECD, Economic Department Working Papers, No. 1552. https://doi.org/10.1787/5ffaab9a-en.

Gostyńska, A. - Tokarski, P. - Toporowski, P. - Wnukowski, D. (eds) (2014): Eurozone Enlargement in Times of Crisis, Challenges for the V4 Countries. Warsaw: PISM.

Győrffy, D. (2009): Structural Change without Trust: Reform Cycles in Hungary and Slovakia. Acta Oeconomica, 59(2): 147-177.

Hare, P. (2020): State-Building for the Market Economy in Eastern Europe. Acta Oeconomica, 70(4): 471491.

Horvath, J. (2014): Political Economy of Accession to the Euro: The Case of Hungary. In: Gostyńska, A. Tokarski, P. - Toporowski, P. - Wnukowski, D. (eds): Eurozone Enlargement in Times of Crisis, Challenges for the V4 Countries. Warsaw: PISM, pp. 59-66.

IMF (2005): Slovak Republic: Staff Report for the 2004 Article IV Consultation. Country Report, No. 05/71 http://dx.doi.org/10.5089/9781451835496.002.

IMF (2012): Slovak Republic - Country Report, No. 12/178 http://dx.doi.org/10.5089/9781475504972.002.

IMF (2017): Slovak Republic - Country Report, No. 17/71 http://dx.doi.org/10.5089/9781475587883.002.

IMF (2019b): World Economic Outlook, October 2019. http://dx.doi.org/10.5089/9781513508214.081.

Johnson, C. (1982): MITI and the Japanese Miracle. Stanford, CA: Stanford University Press. The American Historical Review, 88(1): 158-159.

Kafkadesk (2018): Why Did Czechoslovakia Break up? https://kafkadesk.org/2018/10/30/why-didczechoslovakia-break-up/.

Karácsony, P. - Gaálová, K. - Vasa, L. (2020): Válság után, válság előtt - A visegrádi négyek munkaerőpiacának és versenyképességének alakulása az elmúlt évtizedben (After Crisis, Before Crisis Developments in the Labour Market and Competitiveness of the Visegrad Four over the Past Decade). Külügyi Szemle, 2: 101-120.

Lalinský, T. (2010): Business Competitiveness after Euro, Adoption in Slovakia. National Bank of Slovakia Occasional Paper, No. 3/2010.

Lalinský, T. - Šuster, M. (2018): Vyhodnotenie prínosov eura - po 10 rokoch (Evaluation of the Adoption of Euro - after 10 Years). Národná Banka Slovenska, Note No. 63, 27 December 2018. https://www.nbs. sk/_img/Documents/_komentare/AnalytickeKomentare/2018/AK63_Dopady_eura_v_SK-2018-63.pdf.

Lalinský, T. - Jaanika, M. (2018): The Effect of the Single Currency on Exports: Comparative Firm-Level Evidence. Working Papers of Eesti Pank, No.10/2018.

Machlup, F. (1977): A History of Thought on Economic Integration. New York: Columbia University Press.

Mejstř́ík, M. (2016): Czech Republic - The Present Situation of a Prospective Eurozone Member: Current Challenges during Time of Creative Destruction. Chapter 6. In: Koyama, J. (ed.): The Eurozone Enlargement: Prospect of New EU Member States for Euro Adoption. New York: Nova Science Publishers, pp. 363-368.

Mikloš, I. (2008): Slovakia: A Story of Reforms. In: Bieńkowski, W. - Brada, J. C. - Radło, M. J. (eds): Growth versus Security. London: Palgrave Macmillan, pp. 54-88.

Murach, M. - Wagner, H. - Kim, J. - Park, D. (2018): Avoiding the Middle-Income Trap: Korean Lessons for China? Center for East Asia Macro-Economic Studies, University of Hagen, Discussion Paper, No. 14.

Neményi, J. - Oblath, G. (2012): Az euro bevezetésének újragondolása (Rethinking Hungary’s Prospective Edoption of the Euro). Közgazdasági Szemle, 59(6): 569-684. 
Piroska, D. - Gorelkina, Y - Johnson, J. (2020): Macroprudential Policy on an Uneven Playing Field: Supranational Regulation and Domestic Politics in the EU's Dependent Market Economies. Journal of Common Market Studies, 59(3): 497-517.

Ricz, J. (2016): Developmental States in the 21st Century: Analytical Structure of a New Approach. Centre for Economic and Regional Studies of the Hungarian Academy of Sciences - Institute of World Economics, Working Paper, No. 223.1-35. https://core.ac.uk/download/pdf/78471696.pdf.

Šuster, M. (2006): The Effects of Euro Adoption on the Slovak Economy. National Bank of Slovakia. https:// www.nbs.sk/_img/Documents/PUBLIK/06_kolla.pdf.

Šuster, M. (2014): Slovak Experience with the Euro. In: Gostyńska, A. - Tokarski, P. - Toporowski, P. Wnukowski, D. (eds): Eurozone Enlargement in Times of Crisis, Challenges for the V4 Countries. Warsaw: PISM, pp. 67-74.

Zeman, J. (2012): Costs and Benefits of Slovakia Entering the Euro Area - A Quantitative Evaluation. NBS Working Paper, No. 1/2012.

Žudel, B - Melioris, L. (2016): Five Years in a Balloon - Estimating the Effects of Euro Adoption in Slovakia Using the Synthetic Control Method. OECD Economics Department Working Papers, No. 1317.

Virág, B. (ed.) (2020): Long-Term Sustainability and the Euro. How to Rethink the Maastricht Criteria. Central Bank of Hungary (MNB).

Open Access. This is an open-access article distributed under the terms of the Creative Commons Attribution 4.0 International License (https://creativecommons.org/licenses/by/4.0/), which permits unrestricted use, distribution, and reproduction in any medium, provided the original author and source are credited, a link to the CC License is provided, and changes - if any - are indicated. (SID_1) 